\title{
Quantitative analysis of nitrate and nitrite contents in vegetables commonly consumed in Delta State, Nigeria
}

\author{
I. Onyesom* and P. N. Okoh \\ Department of Biochemistry, PO Box 144, Delta State University, Abraka, Nigeria
}

(Received 14 July 2005 - Revised 7 June 2006 - Accepted 27 June 2006)

\begin{abstract}
Plasma thiocyanate has been reported to be high among cassava-eating populations such as that in Nigeria because of the cyanide content of cassava. Thiocyanate, which is secreted into the stomach contents of animals, has been demonstrated to catalyse the formation of nitrosamines (potent carcinogens) in the stomach from secondary amines and nitrite. The main source of the nitrite precursor in this environment is vegetables, primarily eaten as the chief supplier of proteins. The present study attempts to analyse the levels of nitrate and nitrite in vegetables commonly grown and consumed in Delta State, Nigeria. The nitrate and nitrite contents in green vegetable (Amaranthus spp.), bitter leaf (Vernonia amygdalina), pumpkin (Telfaria occidentalis) and water leaf (Talinum triangulare) grown in different localities of the state were determined by standard analytical procedures. The results show that those vegetables grown in the industrialised urban centres of the state had higher nitrate (223 (SD 71) mg/kg dry weight; $P<0.05$ ) and nitrite (12.6 (SD 1.7) $\mathrm{mg} / \mathrm{kg}$ dry weight; $P>0.05$ ) levels when compared with the same species (188 (SD 77) $\mathrm{mg}$ nitrate/kg dry weight and 10.9 (SD 1.1) $\mathrm{mg}$ nitrite/kg dry weight) cultivated in less industrialised suburbs. We conclude that frequent consumption of such vegetables whose nitrate and nitrite contents are high by cassava-eating individuals might put them at risk of developing stomach cancer and other possible results of nitrate and/or nitrite toxicity. In order to avoid an outbreak in our communities, appropriate agencies should monitor and regulate the release of chemicals into the environment. In the meantime, the cultivation and consumption of vegetables grown in industrialised areas of the state should be discouraged.
\end{abstract}

Thiocyanate: Vegetables: Nitrates: Cassava: Nitrites

Nitrates $\left(\mathrm{NO}_{3}{ }^{-}\right)$and nitrites $\left(\mathrm{NO}_{2}{ }^{-}\right)$are naturally occurring ions; both are products of oxidation of $\mathrm{N}$ by micro-organisms in plants, soil or water and, to a lesser extent, by lightening. Nitrate is the more stable form of oxidised $\mathrm{N}$ but can be reduced by microbial action to nitrite (Beatson, 1978). Vegetables tend to concentrate nitrate ions, especially if they are grown using a high application of $\mathrm{N}$ fertilisers. The concentration of nitrate in vegetables can vary considerably, and may be as much as $3-4 \mathrm{~g} / \mathrm{kg}$ fresh weight, and these levels could have potential health impacts especially in cassavaeating populations (Okoh, 1992).

One of the toxicological implications of nitrate and nitrite ingestion in cassava-eating populations is that thiocyanate, which is present in high amounts in the stomach of such individuals, may act as a catalyst for the nitrosation of amines in the stomach to form carcinogenic nitrosamines (Mirvish, 1983; Maduagwu \& Umoh, 1988; Okoh, 1992). A thiocyanate concentration of $1 \mathrm{mM}$ reduces the optimal $\mathrm{pH}$ for the in vitro nitrosation of $\mathrm{N}$-methylaniline from $\mathrm{pH} 3$ to 1.5 and accelerates the reaction 550 times (Boyland \& Walker, 1974). Although it is difficult to decide what would be the effective concentration of thiocyanate in vivo, it seems reasonable to conclude that if nitrosation is occurring, it will be accelerated in the stomach of animals or human consumers ingesting cyanide and high amounts of nitrites and nitrates in the diet.
Vegetables are important sources of protein in the diets of many Nigerians whose intake of animal protein is very low (Okoh, 1984). Yet vegetables are also the main source of nitrate and nitrite in the diet, accounting for about $75 \%$ of the total intake (Corre \& Breimer, 1979).

The objective of the present study was to determine whether the amount of nitrate and nitrite present in local vegetables commonly consumed in Delta State, Nigeria might be sufficient to cause the associated health problems, and attempt to offer advice to consumers.

\section{Materials and methods \\ Collection of samples}

Four types of vegetables, pumpkin (Telfaria occidentalis), green vegetable (Amaranthus spp.), bitter leaf (Vernonia amygdalina) and water leaf (Talinum triangulare) grown on artificial fertiliser- or manure-free soils, were used in the present study. Sixty-four samples were collected from four different farms in Delta State, Nigeria. Four samples of each vegetable were collected from each farm located in Abraka, Obiaruku, Orazi and Enerhen. The pumpkin samples were randomly collected from different heads in the farm. In the case of the other vegetables that were planted in ridges, samples 
were randomly collected from plants in different ridges. The vegetables were assembled and taken immediately to the laboratory for analysis of their moisture, nitrate and nitrite contents. Sampling was done on 7 January 2003 and repeated on 7 February 2003. A total of eight different collections of each vegetable were taken per location. Each collection was divided into two parts. One part was crushed fresh and prepared for nitrate assay, while the other part was sliced into convenient pieces and allowed to stay at room temperature for about $4 \mathrm{~h}$ before being prepared for nitrite analysis (Atawodi et al. 1991). The time lag is necessary for sufficient reduction of nitrate to nitrite.

\section{Determination of moisture content}

This was determined by drying each sample in an oven at $105^{\circ} \mathrm{C}$ to constant weight. The difference in weight was then expressed as percentage moisture content.

\section{Preparation of oven-dried sample digest for nitrate and nitrite analyses}

About $0.25 \mathrm{~g}$ dried sample was weighed out and placed in a $50 \mathrm{ml}$ conical flask. A solution $(5 \mathrm{ml})$ containing $3.3 \mathrm{ml}$ nitric acid and $1.7 \mathrm{ml}$ perchloric acid was added to the flask under a fumehood. This was allowed to stand overnight at room temperature. The vegetable samples in the flasks were digested in a block digestor at $150^{\circ} \mathrm{C}$ for about $1.5 \mathrm{~h}$. The temperature was increased to $230^{\circ} \mathrm{C}$ and digestion was continued for another $30 \mathrm{~min}$. The temperature was then reduced to $150^{\circ} \mathrm{C}$, and $50 \% \mathrm{HCl}(1 \mathrm{ml})$ was added and the mixture was heated for another $30 \mathrm{~min}$. Each sample was then washed into a $50 \mathrm{ml}$ volumetric flask and made up to mark with water to obtain the digest.

\section{Nitrate assay}

The nitrate contents in the vegetables were determined by the phenoldisulfonic acid method (Association of Official Analytical Chemists, 1975). A portion of the digest $(5 \mathrm{ml})$ was measured into a beaker and evaporated to dryness. Phenoldisulfonic acid $(2 \mathrm{ml})$ was then added and later diluted with $20 \mathrm{ml}$ distilled water. Ammonia solution $(7 \mathrm{ml})$ was then added until a yellow permanent colour developed. The yellow-coloured solution was transferred into $50 \mathrm{ml}$ volumetric flask and made up to mark with distilled water. Absorbance was measured at $410 \mathrm{~nm}$ using a spectrophotometer (Spectronic 21; Milton Roy Co., Rochester, NY, USA).

\section{Nitrite assay}

The nitrite contents in the vegetables were determined by the Nessler's Reagent method (Bassett et al. 1986). A portion of $5 \mathrm{ml}$ digest was measured into a beaker and $1 \mathrm{ml}$ Nessler's reagent was added. The volume was made up to $25 \mathrm{ml}$ with distilled water and absorbance of the resulting orangebrown colloidal product was read at $525 \mathrm{~nm}$ using a spectrophotometer (Spectronic 21; Milton Roy Co.). The AnalaR Grade chemicals used for both assays were supplied by BDH (Poole, Dorset, UK).

\section{Statistical analysis}

The nitrate and nitrite contents in the same type of vegetables collected from different locations, and the contents in the four different vegetables collected from the same location, were compared separately using ANOVA, and the level of statistical significant difference was established at $P<0 \cdot 01$.

\section{Results}

Data obtained from the analyses of the nitrate and nitrite contents in vegetables grown in different locations, and commonly consumed in Delta State, Nigeria are shown in Table 1.

The nitrate contents of Amaranthus spp. (green vegetable) and Talinum triangulare (water leaf) grown in Orazi and Enerhen were significantly higher $(P<0 \cdot 01)$ than those grown in Abraka and Obiaruku, but $V$. amygdalina (bitter leaf) and Telfaria occidentalis (pumpkin) are the vegetables that accumulate the highest levels of nitrate and nitrite. The quantitative differences in the vegetables grown in Enerhen and Orazi are likely to be biologically significant when compared with those cultivated in Obiaruku and Abraka. The amounts of nitrate in bitter leaf and pumpkin were within the range $(133-499 \mathrm{mg} / \mathrm{kg})$ observed to bear strong correlation with the incidence of stomach cancer (Risch et al. 1985). Although, there are yet to be any epidemiological or descriptive data in our environment, the present data suggest a measure of cancer risk.

The mean soil nitrate value for the soil samples collected from industrialised areas was shown to be significantly higher $(P<0.01)$ when compared with the mean value for soil samples obtained from rural centres. Thus, municipal and industrial activities in urban centres, especially oil exploration, might increase the degree of pollution and, hence, contribute to the higher soil nitrate levels (Table 2).

\section{Discussion}

Our major intake of nitrates in foodstuffs comes from vegetables. Nitrates are natural constituents of plants, and are present in large quantities in many vegetables. Vegetables such as beets, celery, lettuce, radishes and spinach contribute about $85-90 \%$ of an adult's dietary intake of nitrate, with nitrate levels ranging from 1.7 to $2.4 \mathrm{~g} / \mathrm{kg}$ food (Corre \& Breimer, 1979).

The most important factors that favour large accumulations of nitrate in vegetables include nitrate-rich soil caused by high levels of fertilisation (Grunderson, 1981), and environmental chemicals (Miroslav \& Vladimir, 1999). The vegetables were cultivated in artificial fertiliser- (or manure)-free soils. Therefore, the results of the present investigation seem to further confirm that environmental chemicals may be a strong determining factor responsible for the nitrate and nitrite distribution and accumulation in the vegetables, since those grown in urban centres had the highest levels. The municipal and industrial activities (especially oil exploration and exploitation) in an area may have probably spun (released) chemicals into the immediate environment (Miroslav \& Vladimir, 1999), and this could probably be implicated for the significant increase $(P<0 \cdot 01)$ in nitrate and nitrite contents in vegetables grown in Enerhen and Orazi compared with those 
Table 1. Nitrate and nitrite contents in vegetables collected during two sampling periods from different locations in Delta State, Nigeria (Mean values and standard deviations)

\begin{tabular}{|c|c|c|c|c|c|}
\hline \multirow[b]{2}{*}{ Vegetable } & \multirow[b]{2}{*}{ Location } & \multicolumn{2}{|c|}{ Nitrate (mg/kg dry wt) } & \multicolumn{2}{|c|}{ Nitrite (mg/kg dry wt) } \\
\hline & & Mean & SD & Mean & SD \\
\hline \multirow{4}{*}{ Green vegetable (Amaranthus spp.) } & Obiaruku & 123 & 9 & $10 \cdot 9$ & 0.1 \\
\hline & Orazi & 163 & 7 & 11.4 & 0.3 \\
\hline & Enerhen & 177 & 11 & 11.9 & 0.5 \\
\hline & All locations & 145 & 9 & $11 \cdot 1$ & 0.4 \\
\hline \multirow{4}{*}{ Bitter leaf (Vernonia amygdalina) } & Obiaruku & 285 & 12 & $13 \cdot 4$ & $0 \cdot 1$ \\
\hline & Orazi & 315 & 16 & $14 \cdot 2$ & 0.3 \\
\hline & Enerhen & 292 & 5 & $14 \cdot 0$ & $0 \cdot 2$ \\
\hline & All locations & 292 & 10 & $13 \cdot 1$ & 0.3 \\
\hline \multirow[t]{4}{*}{ Pumpkin (Telfaria occidentalis) } & Abraka & 230 & 12 & $10 \cdot 9$ & 0.5 \\
\hline & Obiaruku & 237 & 12 & $11 \cdot 1$ & 0.2 \\
\hline & Orazi & 269 & 13 & $13 \cdot 8$ & 0.2 \\
\hline & Enerhen & 274 & 23 & 14.5 & 0.6 \\
\hline \multirow[t]{5}{*}{ Water leaf (Talinum triangulare) } & Abraka & 113 & 8 & $9 \cdot 85$ & 0.3 \\
\hline & Obiaruku & 117 & 8 & 9.99 & 0.5 \\
\hline & Orazi & 144 & 10 & $10 \cdot 6$ & 0.9 \\
\hline & Enerhen & 147 & 5 & $10 \cdot 5$ & 0.2 \\
\hline & All locations & 130 & 8 & $10 \cdot 2$ & 0.5 \\
\hline
\end{tabular}

For details of procedures, see p. 902-903.

grown in Abraka and Obiaruku. The contents of soil nitrate were not determined presumably because nitrate levels in soil might vary hugely from one site to the next, and from 1 month to the next even within the same area depending on the amount of released contaminants and recent fertilisation. Thus, soil nitrate level may not correlate with vegetable level, partly because of the tendency of vegetables to bioaccumulate nitrate. However, Table 2 shows that soils from urban areas (where there is more oil exploration and industrial activities) have higher nitrate levels.

Dietary nitrate is readily absorbed in the stomach and upper small intestine, and is distributed rapidly throughout the body. Roughly, $25 \%$ is recirculated into the saliva, where approximately $20 \%$ is reduced to nitrite by the oral microflora (Okonkwo et al. 1981). If the pH of the stomach is increased, the growth of nitrate-reducing bacteria is allowed and nitrates are converted to nitrites (Zhu et al. 1992). In vivo, nitrite production increases with age (Dykhuizen \& Leifert, 1996) and is enhanced during bacterial infections causing diarrhoea (Zhu et al. 1992).

In the human stomach, nitrites can react with nitrosatable compounds, such as amides and amines, to form N-nitroso compounds (Walker, 1990; Janzowkski \& Eisenbrand, 1995). Some N-nitroso compounds (for example, nitrosamines) are potent carcinogens in animal species (Hartman, 1983), and therefore can be carcinogenic in man (Risch et al. 1985). Some epidemiological studies linking intake of nitrate and nitrite with gastric cancer in man indicated a positive correlation (Dutt et al. 1987). Certain evidence for an association between the intake of nitrate (133-499 parts per million, i.e. $133-499 \mathrm{mg} / \mathrm{kg}$, in vegetables) and the incidence of stomach cancer has been obtained in descriptive epidemiological

Table 2. Nitrate levels in soil samples (parts per million) collected from the Niger Delta area of Nigeria

\begin{tabular}{|c|c|c|c|c|}
\hline \multirow[b]{2}{*}{ Sample code } & \multicolumn{2}{|c|}{ Rural areas $†$} & \multicolumn{2}{|c|}{ Urban and crude oil-impacted areas $\ddagger$} \\
\hline & Obiaruku & Abraka & Sample code & Enerhen and Orazi \\
\hline S1B & 0.30 & - & Maxwell 4 & 113 \\
\hline S4A & 0.16 & - & Maxwell 6 & 181 \\
\hline S3A & - & 0.40 & Maxwell 7 & 158 \\
\hline S1A & 0.03 & - & Maxwell 16 & 45 \\
\hline S5B & - & 1.00 & Maxwell 19 & 135 \\
\hline S2B & - & 0.07 & Maxwell 20 & 68 \\
\hline S4B & 0.40 & - & Maxwell 21 & 158 \\
\hline S2A & $0 \cdot 15$ & - & Maxwell 22 & 113 \\
\hline Mean & 0.21 & 0.32 & & $120^{*}$ \\
\hline SD & 0.14 & 0.41 & & 41.8 \\
\hline
\end{tabular}

${ }^{*} P<0.01$.

†AN Kaizer, EO Adaikpoh and SE Odumuso (unpublished results).

†Iwegbue (2005). 
studies conducted in Chile (Armijo et al. 1981). Since secondary amines and nitrite are present in a number of food sources (Lijinsky \& Epstein, 1970), there has been increasing interest in the possibility that nitrosamines can be formed in vivo. Indeed, there is evidence that nitrosamines are formed in the stomach of rodents (Lijinsky et al. 1973).

It is now known that the nitrosation reaction is catalysed by some anions, particularly thiocyanate (Maduagwu \& Umoh, 1988), and animals fed cassava- and sorghum-based diets containing cyanogenic glucosides convert the cyanide mainly to thiocyanate, which is secreted in large amounts into the stomach (Okoh et al. 1988; Okoh, 1992). These observations might increase the risk of a cassava-eating population to the carcinogenic activities of nitrates and nitrite in vegetables that they consume. A previous report (Eminedoki et al. 1994) has demonstrated that daily consumption of a cassavabased diet by human subjects increases the level of thiocyanate in their serum and urine. Therefore, the control of nitrate and nitrite intake may be important in Delta State, Nigeria, where plasma thiocyanate content is generally high because of the consumption of cassava-based diets, and especially now that the nitrate levels in $V$. amygdalina (bitter leaf), and Telfaria occidentalis (pumpkin) grown in the industrialised regions of the state are within the reference levels reported to be associated with an increased incidence of gastric cancer (Armijo et al. 1981; Dutt et al. 1987).

It is, therefore, important to conduct an environmental impact assessment in Delta State, so that appropriate agencies could start the monitoring and regulation of the release of chemicals into the environment. Meanwhile, the cultivation and consumption of vegetables, especially bitter leaf and pumpkin grown in Orazi, Enerhen, and probably in other municipal and highly industrialised areas of Delta State, Nigeria, should be discouraged in order to avoid the outbreak of nitrate toxicity and associated diseases arising from the increasing release of chemicals into the environment.

\section{References}

Armijo R, Gonzalez A, Orellana M, Coulson AH, Sayre JW \& Detels R (1981) Epidemiology of gastric cancer in Chile: nitrate exposure and stomach cancer frequency. Int J Epidemiol 10, 57-58.

Association of Official Analytical Chemists (1975) Official Methods of Analysis, 13th ed., pp. 653-664. Benjamin Franklin Station, DC: Association of Official Analytical Chemists.

Atawodi SE, Maduagwu EN, Preussmann R \& Spiegelhalder B (1991) Potential of endogenous formation of volatile nitrosamines from Nigerian vegetables and spices. Cancer Lett 57, 219-222.

Bassett J, Denney CR, Jeffery HG \& Mendham J (1986) Vogel's Textbook of Quantitative Inorganic Analysis, 4th ed. London: ELBS/ Longman.

Beatson CG (1978) Methaemoglobinaemia - nitrates in drinking water. Environ Health 86, 31-33.

Boyland E \& Walker SA (1974) Effect of thiocyanate on nitrosation of amines. Nature 284, 601-602.
Corre WJ \& Breimer T (1979) Nitrate and Nitrite in Vegetables. Wageningen, The Netherlands: Centre for Agricultural Publishing and Documentation.

Dutt MC, Lim HY \& Chew RKH (1987) Nitrate consumption and the incidence of cancer in Singapore. Food Chem Toxicol 25, $515-518$.

Dykhuizen N \& Leifert C (1996) Antimicrobial effect of acidified nitrite on gut pathogens: importance of dietary nitrate in host defence. Antimicrob Agents Chemotherap 40, $1422-1425$.

Eminedoki DG, Monanu MO \& Anosike EO (1994) Thiocyanate levels of mainly dietary origin in serum and urine from a human population sample in Port Harcourt, Nigeria. Plant Foods Hum Nutr 46, 277-285.

Grunderson DJ (1981) Effect of nitrogen fertilizer on nitrate contents of field vegetables. J Sci Food Agric (Camb) 37, 373-383.

Hartman PE (1983) Review: Putative mutagens and carcinogenesis in foods - nitrate/nitrite ingestion and gastric cancer mortality. Environ Mutagens 5, 111-121.

Iwegbue CMA (2005) Heavy metals and physiochemistry of soils, sediments and surface water of crude oil impacted area in the Niger Delta. M. Phil Thesis, Rivers State University of Science and Technology, Port Harcourt, Nigeria, pp. 198.

Janzowkski C \& Eisenbrand G (1995) Aspects to be considered for risk assessment concerning endogenously formed N-nitroso compounds. In Health Aspects of Nitrate and its Metabolites (Particularly Nitrite), Proceedings of the International Workshop, Bilthoven, Netherlands, 8-10 November 1994, pp. 313-330. Strasbourg: Council of Europe Press.

Lijinsky W \& Epstein SS (1970) Nitrosamines as environmental carcinogens. Nature 225, 21-23.

Lijinsky W, Taylor HW, Snyder C \& Nettesheim P (1973) Malignant tumours of liver and lung in rat fed aminopyrine or heptamethyleneimine, together with nitrite. Nature 244, 176-178.

Maduagwu EN \& Umoh IB (1988) Dietary thiocyanate and N-nitrosation in vivo in Wistrar rats. Ann Nutr Metab 32, 30-37.

Miroslav R \& Vladimir BN (1999) Practical Environmental Analysis. Cambridge, UK: Royal Society of Chemistry.

Mirvish SS (1983) The etiology of gastric cancer, intra-gastric nitrosamide formation and other theories. J Natl Cancer Inst 71, 630-636.

Okoh PN (1984) An assessment of the protein, mineral and vitamins losses in sun-dried Nigerian vegetables. Nutr Rep Int 29, 359-364.

Okoh PN (1992) The metabolic fate of cyanide in animals. Nig J Physiol Sci 8, 1-9.

Okoh PN, Ikediobi CO \& Olugboji O (1988) The fate in the rate of ingested dhurrin present in malted sorghum grain. Food Chem 29, 299-301.

Okonkwo PO, Nwokolo C \& Onwuamaeze CI (1981) Dietary nitrate and carcinogenesis in the Nigerian environment. Nig J Nutr Sci $\mathbf{2}$, $9-13$.

Risch HA, Jain M, Choi NW, Fodor JG, Pfeiffer CJ, Howe GR, Harrison LW, Craib KJP \& Miller AB (1985) Dietary factors and the incidence of cancer of the stomach. Am J Epidemiol 122, 947-949.

Walker R (1990) Nitrates, nitrites and N-nitroso compounds: a review of the occurrence in food and diet and the toxicological implications. Food Addict Contam 7, 717-768.

Zhu L, Gunn C \& Beckman JS (1992) Bacterial activity of peroxynitrite. Arch Biochem Biophys 295, 452-454. 